\title{
Amyloidosis: the use of the Daratumumab
}

\author{
Adriano Anzai ${ }^{1}$ \\ (iD) Armelin Utino ${ }^{\mathbf{1}}$ \\ (iD) Haroldo Katayama ${ }^{1}$ \\ (iD) Ighor A. Z. Spir ${ }^{1}$ \\ Marcio A. Lemos ${ }^{1}$ \\ (iD) Mauricio Anhesini ${ }^{1}$ \\ Oswaldo S. Tiezzi \\ (iD) Patricia R. N. Spir ${ }^{1}$ \\ (iD) Pericles Otani ${ }^{1}$ \\ Wanderley M. Bernardo
}

1. Grupo de M.B. E - Presidente Prudente, Presidente Prudente, SP, Brasil. 2. Coordenador do Programa Diretrizes da Associacao Medica Brasileira, Sao Paulo, SP, Brasil.

QUESTION: What is the role of daratumumab in the treatment of Amyloidosis?

ANSWER: The use of daratumumab in patients with clinical symptoms of amyloidosis currently should not be recommended due to the weakness of the evidence available to support it. ${ }^{1}$

\section{REFERENCES}

1. Anzai, Adriano et. al. Use of daratumumab in patients with amyloidosis. Rev Assoc Med Bras 2020; 66(11):1468-1471. 